DOI: $10.2478 /$ lpts-2019-0032

\title{
SYNERGY BETWEEN THE NATURAL GAS AND RES IN ENHANCEMENT OF SECURITY OF ENERGY SUPPLY IN THE BALTIC COUNTRIES (PROBLEM STATEMENT)
}

\author{
J. Savickis ${ }^{1}$, N. Zeltins ${ }^{2}$, L. Jansons ${ }^{2}$ \\ ${ }^{1}$ ITERA Latvija \\ 50 Skanstes Str., Riga, LV-1013, LATVIA \\ ${ }^{2}$ Riga Technical University, \\ Faculty of Power and Electrical Engineering, Institute of Power Engineering \\ 12-1 Āzenes Str., Riga, LV-1048, LATVIA \\ E-mail: zeltinsh@gmail.com

\begin{abstract}
Although the natural gas and renewable energy sources are two significant elements of the Baltic primary energy mix both today and in foreseeable future, the competitive edge of their usage often prevails over possibilities of mutually beneficial coexistence. Universally both forms of energy are often described as key elements of a transition to a cleaner and more secure energy future (low-carbon economy), but regionally much of the current discourse considers each in isolation or concentrates on the competitive impacts of one on the other. The paper outlines several potential avenues and further research trends of synergies between the natural gas, a proven fastreacting fossil fuel, and RES as seen from viewpoints of the Baltic energy sector sustainability and security of energy supply.
\end{abstract}

Keywords: decarbonisation, fast-reacting fossil fuels, natural gas, renewable energy, transitional technologies, synergy

\section{INTRODUCTION}

In a global scale, consumption of natural gas and renewable energy (RES) has grown significantly in recent decades. Since 1990, natural gas consumption worldwide has doubled from 2000 billion cubic meters $\left(\mathrm{m}^{3}\right)$ in 1990 to almost 4000 $\left(\mathrm{m}^{3}\right)$ in 2018. In the United States alone natural gas demand increased by $10 \%$ in 2018, the highest growth seen in the past 30 years, triggered by the power sector development (additional 15 gigawatts $(\mathrm{GW})$ of new gas-fired power plants) and increasing consumption in the building sector. In 2018, RES covered $36 \%$ of the power mix (including transport sector) in Europe, $26 \%$ in China and around $18 \%$ in the United States, India and Japan. The share of wind and solar in the global power 
mix rose last year by modest $0.8 \%$, but, as power generation accounted for more than $30 \%$ of the total additional power production, the actual rise resulted in $16 \%$ for solar power and $15 \%$ for wind energy [1].

In the European Union (EU), past decades depict a constant, gradual decline in the natural gas and growth in RES. The share of RES in gross final energy consumption has almost doubled between 2016 and 2005. It reached $17 \%$ in 2016 and $17.4 \%$ in 2017. Overall increase in a share of RES in final energy consumption in the EU has slowed down a bit just recently, as increasing energy demand and lack of significant progress in a transport sector decarbonisation imperil the achievement of both 2020 targets on RES and energy efficiency [2]. At the same time, the statistics shows that consumption of the natural gas in the EU has been quite stable in recent few years and even shown signs of some positive dynamics. In 2017, gross consumption of natural gas in the EU increased by $3.7 \%$ compared with 2016, to reach 18587 thousand terajoules (TJ), but its use in the European energy production continued to demonstrate a downward pattern [3].

For large-scale natural gas infrastructure in the EU, in order to stay relevant, fulfillment of additional functions beyond its traditional role of transporting fossil fuel from the point A to point B is expected. Sustainability of the future natural gas networks will increasingly depend on their versatility, flexibility, and pricing of such commodities like carbon dioxide $\left(\mathrm{CO}_{2}\right)$ emissions and land use. Europe's natural gas infrastructure is a valuable asset, which should not be only preserved for sake of preservation, but utilised rationally to increase energy sector overall sustainability and enhance security of energy supply. The possibility to establish dynamic, integrated synergy between natural gas - regardless of its transportation means and final consumption sector - and RES till 2030 and beyond will define its role in decarbonized EU's energy future for decades to come [4], [5].

Optimistic prospects of growth in the natural gas consumption will most definitely await Europe's transport sector, where the role of LNG (liquefied natural gas) and $\mathrm{CNG}$ (compressed natural gas) is bound to increase in road and maritime (inland waterway) transport in the nearest future. There are rather rare examples of common European energy legislation, which directly connects decarbonisation of economy (transport or energy production sectors) with acknowledgment of the natural gas sustainability potential. Notable example of this rarity perhaps is Alternative Fuels Infrastructure Directive (2014/94/EU) supporting use of CNG and LNG as transport fuel and LNG as maritime and inland waterway fleet fuel [6].

In energy production and consumption sectors, no corresponding natural gas supporting pieces of legislation are in force, so there the natural gas sector should explore potential synergy avenues opened by new cornerstones of the EU energy policy framework - such as provisions of Energy Union (EEU) Governance [7], [8]. The National Energy and Climate Plans (NECPs) as the main tool of the EEU Governance for achieving the EU's 2030 climate and energy targets, clearly focus on at least: 1) $40 \%$ cuts in greenhouse gas (GHG) emissions; 2) $32 \%$ share for RES; 3) $32.5 \%$ improvement in energy efficiency [9], [10]. These targets functionally supplement and specify five dimensions of the EEU for a period between 2021 and 2030, which are: 1) energy security; 2) the internal energy market; 3 ) energy efficiency; 4) decarbonisation of the economy; 5) research, innovation and competitiveness [11]. 
Decarbonisation of the economy is the only one of five dimensions, which allows for a kind of duality in terms of interpretation. On the one hand, its aim is a significant reduction of GHG emission, an increase in the share of RES in all energy and transport related sectors of national economies and an increase in the implementation of economically sound industrial scale $\mathrm{CO}_{2}$ capture and storage solutions. On the other hand, this dimension relates to the so-called transitional technologies as well - mainly fossil generation solutions with a minimal environmental impact (maximal $\mathrm{CO}_{2}$ neutrality) [5], [12].

Among these transitional technologies, which can provide: 1) stable base load generation during building and enhancement of large-scale market competitive RES; 2) reliable peak load generation during fluctuation in energy production from RES, only two stand out as most likely midterm coupling candidates (especially important for wind energy installations). They are nuclear generation units (reactors) and natural gas power plants [13]. Table 1 shows that in terms of direct $\mathrm{CO}_{2}$ emissions per kilogram/kilowatt-hour $(\mathrm{kg} / \mathrm{kWh})$ and kilogram/gigajoule $(\mathrm{kg} / \mathrm{GJ})$, natural gas and nuclear reactors currently are less $\mathrm{CO}_{2}$ intensive fossil fuels (generation sources) available.

Table 1

Direct $\mathrm{CO}_{2}$ Emissions of Various Fuels

\begin{tabular}{|l|c|c|}
\hline Fuel & Emissions: $\mathrm{kg} / \mathrm{kWh}$ & Emissions: $\mathrm{kg} / \mathrm{GJ}$ \\
\hline Wood ${ }^{*}$ & 0.39 & 109.6 \\
\hline Peat & 0.38 & 106.0 \\
\hline Lignite & 0.36 & 101.2 \\
\hline Hard coal & 0.34 & 94.6 \\
\hline Fuel oil & 0.28 & 77.4 \\
\hline Diesel & 0.27 & 74,1 \\
\hline Crude oil & 0.26 & 73.3 \\
\hline Kerosene & 0.26 & 71.5 \\
\hline Gasoline & 0.25 & 69.3 \\
\hline Natural gas & 0.20 & 56.1 \\
\hline Nuclear power reactors & 0 & 0 \\
\hline
\end{tabular}

* not sustainable used without reforestation

Source: Fachbuch Regenerative Energiesysteme und UBA

If nuclear energy provides $\mathrm{CO}_{2}$ free base load generation, which can be successfully coupled with various RES and can also provide hydrogen production [14], the natural gas can ensure both base load generation (in cogeneration and condensation modes) and reliable peak load coverage thanks to its flexibility and fast fast-reaction properties [5]. Fast-reacting fossil fuel installations - such as highly efficient, combined-cycle, natural gas-fired power plants - in midterm EU and Baltic perspective could be regarded as one of the most viable options to: 1) ensure largescale RES development, 2) guarantee energy security of supply, 3) avoid energy system crashes or interruptions (brownouts and blackouts); 4) support development 
and enhancement of existing large-scale natural gas transportation, storage and distribution networks. To date, large-scale storage of electricity cannot be easily and economically performed, so the amount of power generated from RES at the given time must exactly match the amount of actual demand [15]. Variability in generation has been identified as a significant barrier to the integration of large-scale wind and solar resources into energy systems [17], [13]. Currently, given their relatively low penetration in the Baltic States, the integration of RES has not required changes in system operations. Peak load generation technologies such as gas turbines have been used to compensate for variability, alongside other load-following generation technologies, such as large hydro power plants (HPPs). The same large RES balancing strategy is used in many European countries [5].

\section{LARGE-SCALE WIND INTALLATIONS IN THE BALTIC COUNTRIES}

In three Baltic countries, in foreseeable future large-scale RES, requiring reliable fossil fuel backup, could be onshore and offshore wind farms and, possibly, some solar PV installations. To date, in the three countries total installed wind capacity nearly reaches 900 megawatts (MW), [18], [19], [20] with Lithuania being a leader in the Baltic wind energy sector. There are currently 23 wind parks operating in Lithuania, with a combined capacity of 539MW. In 2018, they produced 1.1 terawatthour (TWh) of electricity. By comparison, wind parks produced the largest amount of electricity in the Lithuania's wind energy history in 2017, reaching 1.3TWh [18].

As of the end of December 2018, there were 139 wind turbines installed in Estonia with a total installed capacity of $309.96 \mathrm{MW}$. The last wind park commissioned to date is Tooma II with three turbines and total installed capacity of $7.05 \mathrm{MW}$. It was inaugurated in 2016. In 2018, wind parks in Estonia produced 0.59TWh of electricity. Due to unfavourable wind conditions, production of energy decreased in 2018 by $12 \%$ but remained at a similar level with 2016 [19].

In Latvia, installed capacity of wind is much more modest, and it riches around $67 \mathrm{MW}$ from which only $20.7 \mathrm{MW}$ are connected to the transmission network. Wind parks are mainly located close to the Baltic coast [20]. Future development of large-scale offshore and onshore wind energy installations still remains unclear as the Latvian National Energy and Climate Plan (LNECP) predicts rapid development of these installations only after 2023, with a possibility that in upcoming years (nonspecified term) new offshore installations with total installed capacity up to $100 \mathrm{MW}$ could be built [21].

Historical study on RES development in 26 member states of the Organization for Economic Cooperation and Development (OECD) found that between 1990 and 2013 flexible fossil fuel backup capacity required for wind and solar was almost equal to the installed RES capacity: $1 \%$ increase in the share of fast-reacting fossil technologies was associated with a $0.88 \%$ increase in RES capacity in the long term [5]. It means that currently the Baltic countries require about $800 \mathrm{MW}$ of fossil fuel backup capacity for balancing their existing wind power installations, which cover almost all Riga combined heat and power plant 2 (Riga CHPP 2) electric load in cogeneration mode (two units combined: $832 \mathrm{MW}$ ) [25]. At the same time, rarely 
more than $10 \%$ of wind installed capacities are producing energy simultaneously, so for extremely modest Baltic wind balancing only about 80MW would be required on a regular basis.

Synergy between the natural gas and RES in enhancement of security of energy supply in the Baltic region will become crucial when scarcity of flexible and market competitive fast-reacting base load generation (or base load generation as such) will step in after shutting down most of the Estonian oil shale generation units around 2020-2023 and the Baltic transmission systems' synchronisation area change in 2025 .

\section{FAST-REACTING NATURAL GAS GENERATION IN LATVIA}

There are many options that might trigger achievement of the EU's 2030 climate and energy targets and enhance regional energy security. Diversification of the natural gas supply to the EU countries and internal market interconnection boost ensure reliability and sustainability of the natural gas both as power plants and in transport fuel [4]. Due to its physical properties, natural gas and its transitional technologies provide highly efficient energy production for all customer groups, from households to highly efficient cogeneration plants. State-of-the-art natural gas combustion technologies ensure competitive efficiency rates $(>90 \%)$ and are fully automated, depending on air temperature, day of the week and hours of the day, providing rational energy production and a high level of overall performance. Natural gas technologies therefore could be regarded as one of the most promising and cost effective transitional technologies for at least next few decades [23] in both EU and the Baltic countries, providing stable and reliable backup for emerging largescale RES, in particular wind energy installations [24].

To date, RES generation backup has also been mostly provided through different fossil based technologies. Most base load fossil generation, for example, coal power plants running in condensation mode and nuclear power plants, cannot easily compensate for RES variability due to slow reacting times and high capital costs. Fast-reacting fossil technologies, which include most natural gas generation technologies (combined heat and power, integrated gasification combined cycle etc.) are characterised by quick ramp-up times, lower capital costs and modularity [25]. They are thus particularly suitable to meet peak demand and mitigate the variability of RES, especially large-scale wind installations [24].

Riga combined heat and power plants (Riga CHPP 1 and 2) are the most important base load generation units in Latvia and one of crucial base load units in the Baltic countries. With combined electric load of two Riga CHPP 2 units (832 MW (cogeneration mode) and $881 \mathrm{MW}$ (condensation mode)) and one unit of Riga CHP 1 (144 MW), plants are mostly operated in the highly efficient cogeneration mode according to the thermal energy demand, which in turn depends on weather conditions and the duration of the heating season in Riga. Electricity generation at Riga CHPPs, especially Riga CHPP 2, is also directly influenced by the following market preconditions: electricity demand, natural gas and $\mathrm{CO}_{2}$ price [22]. 
Riga CHPP 1 and 2 can be flexibly adjusted to the electricity market conditions and can cover Latvian electricity consumption almost completely when electricity import from foreign countries is limited. In 2018, both plants played a very important role in meeting the demand for electricity, when dry weather conditions significantly reduced the hydro energy output both in Latvia and throughout the Nord Pool region, and capacity shortages frequently hit regional interconnections. Last year Riga CHPPs generated about 2.6TWh of electricity and 2TWh of thermal energy, a $15 \%$ decrease compared to 2017. The drop was due to the increase in competition in the thermal energy market: four new heat producers started operating in the thermal energy zones of Riga CHPPs at the end of 2017 - beginning of 2018.

Riga CHPPs' capability of fast start-ups is the most advertised flexibility feature in condensation and cogeneration modes. Cold state start-up time for both units of Riga CHPP 2 is $>55$ hours (h), where "cold state" means that steam turbine temperature is below $210^{\circ} \mathrm{C}$. Time to launch cogeneration unit into operation from warm state (steam turbine temperature is in the range between $210^{\circ} \mathrm{C}-410^{\circ} \mathrm{C}$ ) takes $8-55 \mathrm{~h}$, but from hot state (steam turbine temperature is above $410{ }^{\circ} \mathrm{C}$ ) $-<8 \mathrm{~h}$. The rate of load increase and decrease corresponds to $16 \mathrm{MW} /$ minute. Number of allowed start-ups per year for units 1 and 2 are about 50 and 70 [25]. Therefore, Riga CHPP 2 generation units can provide a quick and prompt response to load fluctuations not only in Latvia, but also in other Baltic countries. In future, natural generation technologies will become even more flexible and responsive to market and physical demand dynamics. Even today there are natural gas CHPPs in operation in Europe, where new generation technologies provide maximum power output in less than 30 minutes (starting steam turbine temperature not specified), with a ramp rate of more than 50MW/minute [26].

Reduction of start-up time also reduces the adverse influence of modes on power plant operation, life time and energy production costs. The main economic gains are: 1) operating benefits lead to lower start-up costs; 2) ancillary services prompt to additional earning through ancillary service products; 3) market arbitrage induces higher profit trough usage of high price market [27]. Market compatible electricity wholesale price when one unit of Riga CHPP 2 can be operated in condensation mode is about $50 \mathrm{EUR} / \mathrm{MWh}$ (average day-ahead price in the Latvian Nordpool bidding area in January - July 2019 was 46.48 EUR/MWh).

In addition to flexibility provided by Riga CHPP 1 and 2, large-scale hydro is available in the Baltics thanks to three Daugava HPPs - the biggest in Latvia and the Baltic countries. As the Daugava is the river flowing across plains and the functionality of HPPs does not require energy consumption for reservoir filling, their ability to generate electricity depends on the water inflow of the Daugava River. In years with normal inflow levels (up to 200-250 cubic meters per second ( $\mathrm{m}^{3} / \mathrm{s}$ )), HPPs can operate at full capacity during the spring flooding season, which lasts for about one to two months annually. Outside the flooding season, the HPPs provide for the possibility to accumulate water and generate electricity when the demand and prices on the exchange are the highest. Daugava HPPs and Riga CHPPs work functionally sound together, as Riga CHPPs provide the major share of base load generation, but Daugava HPPs, whose share of base load generation fluctuates between 150 to about $350 \mathrm{MW}$ on seasonal basis, cover peak demand [22]. 


\section{THE INCREASING ROLE OF CNG - BIOMETHANE SYNERGY IN TRANSPORT}

Rare primary energy source can compete with the natural gas in diversity of use; however, dynamics of the natural gas market in Latvia over the past decades can be described as "free falling" with a rather modest outlook for significant positive changes in the nearest future. Natural gas consumption in Latvia decreased by about $40 \%$ in last ten years, but since 1995, this decline had been even more impressive, reaching about $60 \%$ (from almost 3 billion cubic meters $\left(\mathrm{m}^{3}\right)$ in 1995 to 1.2 billion $\mathrm{m}^{3}$ in 2018) [28]. Almost the same pattern of decreasing natural gas consumption was observed in Estonia and Lithuania as well. Furthermore, Latvia's natural gas transportation and storage infrastructure, designed and built for much more intensive exploitation, now is used for only $40 \%$ on the annual basis [20]. But at the same time, Latvia's natural gas security of supply rate (according to $\mathrm{N}-1$ criterion and thanks to Inčukalns underground gas storage facility) is one of the highest in the EU [29], [30], [4].

While many European countries have quite reserved outlook towards sustainability of the natural gas, in other parts of the world, for example, in the US and Canada, moods are absolutely different. In these countries, natural gas, especially LNG or CNG used in municipal transport, is considered not only environmentally friendly fuel - a vital contributor to decarbonisation of economy, but also a "green" and sustainable form of primary energy [12]. The EU's Alternative Fuels Infrastructure Directive (2014/94/EU) is supporting the use of CNG and LNG as transport fuel and LNG as maritime and inland waterway fleet fuel. It establishes an obligation for the EU Member States to make LNG available in the maritime ports of the Trans-European Network of Transport (TEN-T) by 31 December 2025. It also addresses inland ports, which need to provide LNG bunkering infrastructure by 31 December 2030. Following the provisions of the Directive, Member States are obligated to prepare corresponding national policy frameworks to establish more than 250 LNG refuelling points throughout the EU until late 2025 [6].

The same document also establishes that an appropriate number of $\mathrm{CNG}$ refuelling points accessible to the public are put in place by 31 December 2020, in order to ensure that $\mathrm{CNG}$ vehicles can circulate in cities and other densely populated areas. Additionally, by the end of December 2025 Member States shall ensure that an appropriate number of $\mathrm{CNG}$ refuelling points are put in place, at least along the existing TEN-T Core Network, to guarantee circulation of CNG vehicles throughout the EU [6].

Biomethane and natural gas are recommended as fuels in urban traffic; the advantages of methane fuels related to noise reduction and emissions of harmful substances predispose them to be used in such fleets of vehicles as private cars, buses, municipal and delivery vehicles and taxis. Moreover, biomethane is currently the only biofuel with the same chemical composition as the fossil fuel it replaces. It can therefore be mixed with natural gas in any ratio, without negative consequences for the engine [31].

In the EU, demand for energy in transport is constantly growing, and, at the same time, the transport sector is almost entirely dependent on $\mathrm{CO}_{2}$ intensive oil 
based fuels. Its pollution is responsible for more than $30 \%$ of GHG emissions in Europe. Even in case of the most optimistic scenario regarding biomethane use in the EU future transport fuel mix, it could only cover $6.2 \%-9.5 \%$ of all transport energy needs. Only around $4 \%$ of gas consumed in the EU comes from RES, and the share of "green" gas transported via a distribution grid makes up just $0.5 \%$ compared to almost $30 \%$ of RES in electricity generation, transportation and distribution. Less than $1 \%$ of biomethane produced is currently used in transport [12]. In 2018, the EU leaders in number of CNG (CNG-biomethane) filling stations were Italy (1044), Germany (868), the Netherlands (176) and Sweden (174), but the Baltic States had just 18 CNG at all (Estonia - 13 (in 2019 - 15), Lithuania - 4 (in 2019 - 5), Latvia - 1 (in 2019 - 2)) [7], [17] [13]. Table 2 shows the number of CNG filling stations in the European countries in 2018 and the average price of fuel by country.

Along with second-generation biofuels and electric vehicles, biomethane is a promising option for enhancement of sustainable mobility [32]. The use of biomethane in energy production, consumption and transport opens one of the most important natural gas and RES synergy avenues, where the natural gas distribution grids can be used for transportation of biomethane. Such countries as Sweden, Germany, Italy and Estonia may serve as an example of effective implementation of CNG and CNG - biomethane partnership in transport. However, in these countries starting platforms are different: in Sweden natural gas grids are not used for biomethane transportation, but in Germany almost all biomethane is injected into natural gas grids. Non-grid transportation options are used only when natural gas grids (mostly, distribution networks) are not available in the vicinity of biogas production plants or are not developed at all, but injection into natural gas grids can be performed, when natural gas distribution networks are available and especially designed connection points are made in order to receive biomethane [32], [12].

While Latvia has just begun development of commercial CNG filling stations - the first commercial CNG filling station owned by JSC "Virši-A" was put into operation on May 16 this year in Jēkabpils [33] for serving seven CNG buses purchased by local municipal transportation authority -, its northern neighbour Estonia already has a lot of experience to share. The development of the Estonian CNG sector has come a long way, which stretches for almost a decade. First steps in its development were taken in 2008-2009. Interest of potential customers and availability of fiscal instruments for promotion of CNG played an important role in the process. In particular, during the start-up period for introduction of CNG in Estonia excise duties on natural gas as transport fuel were not collected at all. Currently excise duty amounts to 47.32 euro (EUR) per $1000 \mathrm{~m}^{3}$, while excise duty free start-up is now applied to biomethane [34], [35], [16].

Geographically, CNG filling stations are spread evenly throughout the country, making CNG mobility easy, safe and reliable - without the risk of being left without a possibility to fuel a vehicle. Many stations have rather high performance capacities: for example, the CNG filling station in Parnu has a capacity of $17000 \mathrm{~m}^{3 /}$ month (which corresponds to refueling demand of 18 city buses) [16]. The largest CNG filling station in Estonia to date is 48-unit refueling station in Tartu, put into operation in July, 2019. 64 new buses serving Tartu urban transportation network will be refueling at the new station. The section open for public can be used by the 
transport companies of Tartu region and private individuals [36]. In 2018, in Estonia 8.2 million $\mathrm{m}^{3}$ of $\mathrm{CNG}$ was sold, 4.5 million $\mathrm{m}^{3}$ of which was biomethane [34]. Figure 1 shows dynamics of the Estonian CNG sales during period between 2009 and 2018.

Table 2

The Number of CNG Filling Stations in the European Countries and the Average Price of Resources $(€ / \mathrm{kg})$

\begin{tabular}{|c|c|c|}
\hline Country & Number of stations & Average price of resources $(€ / \mathrm{kg})$ \\
\hline Austria & 169 & 0.99 \\
\hline Belarus* & 44 & 0.32 \\
\hline Bosnia and Herzegovina * & 2 & - \\
\hline Belgium & 100 & $0.94-1.07$ \\
\hline Bulgaria & 114 & 0.75 \\
\hline Croatia & 2 & 1.34 \\
\hline Czech Republic & 171 & 0.97 \\
\hline Denmark & 16 & 1.6 \\
\hline Estonia & 13 & $0.86-0.9$ \\
\hline Finland & 37 & 1.34 \\
\hline France & 77 & 1.24 \\
\hline Germany & 868 & $0.95-1.08$ \\
\hline Great Britain & 6 & 0.78 \\
\hline Greece & 13 & 0.86 \\
\hline Hungary & 18 & 1.08 \\
\hline Iceland* & 5 & 1.31 \\
\hline Italy & 1044 & 0.96 \\
\hline Lichtenstein* & 2 & 1.33 \\
\hline Lithuania & 4 & $0.94 * *$ \\
\hline Luxemburg & 4 & 0.68 \\
\hline Macedonia* & 5 & 0.62 \\
\hline Moldova* & 19 & 0.40 \\
\hline Norway* & 20 & 1.77 \\
\hline Netherlands & 176 & 1.13 \\
\hline Poland & 23 & $0.87 * *$ \\
\hline Portugal & 7 & $0.92 * *$ \\
\hline Romania & 3 & 0.94 \\
\hline Russian Federation* & 235 & $0.27 * *$ \\
\hline Serbia* & 21 & 0.77 \\
\hline Slovakia & 12 & 1.08 \\
\hline Slovenia & 5 & 1.1 \\
\hline Spain & 61 & 0.94 \\
\hline Sweden & 174 & 1.87 \\
\hline Switzerland* & 146 & 1.32 \\
\hline Turkey* & 19 & $0.74 * *$ \\
\hline Ukraine* & 205 & $0.45^{* *}$ \\
\hline
\end{tabular}

* non-EU states $\quad * * € / \mathrm{m}^{3}$

Source: cngeurope.com 


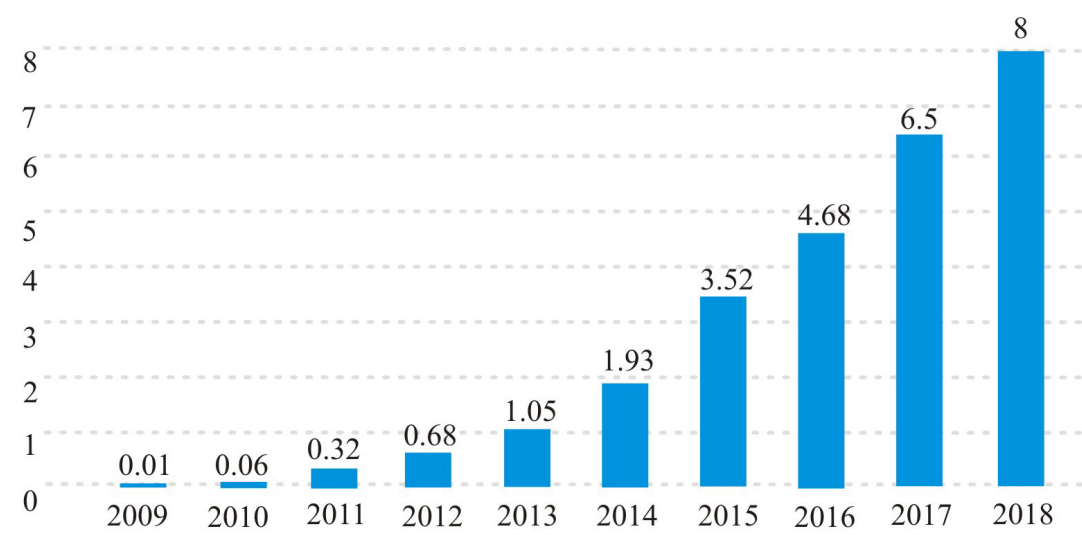

Fig. 1. CNG sales in Estonia (2009-2018, million $\mathrm{m}^{3}$ ).

Source: JSC Eesti Gaas

Furthermore, Estonia allocated EUR 2 million in 2018 as support funds for the construction of biomethane plants (covering up to $35 \%$ of construction costs or a maximum of EUR 350000 per project).

In order to catch up with its Baltic neighbours and to boost sales of natural gas as a transport fuel, the Latvian natural gas distribution system operator is estimating that at least 5 commercial CNG filling stations will be in operation in Latvia by 2020 . Owner of Jēkabpils CNG filling station JSC "Virši-A" is willing to open two more station in 2019 in Riga [33].

In 2018, research was conducted in order to establish where conventional fuel filling stations are located in Latvia with proximity to the natural gas distribution network (potential locations for CNG filling units). The research results demonstrated that out of 250 stations owned by four operators natural gas grid connections $(\mathrm{P}<4 \mathrm{bar}$ min.; 300m or closer) were available in 130 places. Low-pressure natural gas grid connections ( $\mathrm{P}<50 \mathrm{mbar} ; 100 \mathrm{~m}$ or closer) were available in 21 places, but a lack of natural gas distribution grid proximity was verified in 99 places. Table 3 reflects a breakdown of data, showing stations with grid connection proximity and lack of grid connection proximity [35].

Table 3

Existing Filling Stations in Latvia and their Proximity to Natural Gas Distribution Network

\begin{tabular}{|l|c|c|c|c|c|}
\hline & Operator 1 & Operator 2 & Operator 3 & Operator 4 & Total \\
\hline Number of filling stations & 77 & 62 & 54 & 57 & 250 \\
\hline $\begin{array}{l}\text { Natural gas grid connections available } \\
(\mathrm{P}<4 \text { bar min.): 300m or closer }\end{array}$ & 47 & 37 & 27 & 19 & 130 \\
\hline $\begin{array}{l}\text { Low-pressure natural gas grid } \\
\text { connections available (P<50mbar): } \\
100 \mathrm{~m} \text { or closer }\end{array}$ & 9 & 6 & 5 & 1 & 21 \\
\hline $\begin{array}{l}\text { No natural gas distribution grid } \\
\text { available nearby }\end{array}$ & 21 & 19 & 22 & 37 & 99 \\
\hline
\end{tabular}

Source: JSC Gaso 
Development of expanded and prosperous CNG - biomethane market in the upcoming decade could be regarded as one of the cornerstones in both decarbonisation of the transport sector in the Baltic countries and revitalisation of national and regional natural gas markets, which struggle with consequences of a decrease in twenty yearlong natural gas consumption and gradual changes in the market layout. It could also benefit to more intensive use of natural gas transportation, storage and distribution infrastructure, especially, if both CNG fueled vehicle and LNG fueled heavy duty vehicle segments take off in next five years as required by Directive 2014/94/EU. It reads that an appropriate number of refueling points for LNG accessible to the public must be put in place by 31 December 2025, at least along the existing TEN-T Core Network, in order to ensure that LNG heavy-duty vehicles can circulate throughout the EU [6] (according to certain estimates, LNG filing stations should be located max. $400 \mathrm{~km}$ apart along existing TEN-T Core Network and other main highways) [34].

\section{CONCLUSIONS}

In midterm perspective (2030-2040), the natural gas represents the shortest and least costly path towards decarbonisation of the energy sector in the Baltic countries, increasing its overall efficiency and level of security of supply, especially if reasonably coupled with various RES, which might be a viable option for the regional electricity generation and transportation sectors. The Baltic countries are a specific EU region, which in next ten years will face several challenges demanding meticulous planning of installed base load capacity development, such as change of energy system synchronization area in 2025, decreasing historical fleet of fossil base load generation in Estonia, transport sector decarbonisation efforts and rise in variable RES generation (large-scale wind installations) after 2020 [37].

In order to enhance the Baltic energy sector sustainability and security of energy supply via synergy between the natural gas and RES, the following conclusions can be drawn:

1. the parity between existing large-scale natural gas generation and largescale RES should be clearly established, as large-scale natural gas generation provides reliable and flexible backup for large-scale RES, especially wind installations, which are most likely new large-scale RES to be actively developed in the Baltics [37];

2. parity of large-scale natural gas generation and RES benefits both sides: for RES it is a reliable backup, for the natural gas - predictable market positions and ability to enhance their flexibility parameters and the natural gas use even more;

3. this parity, as well as wider use of $\mathrm{CNG} / \mathrm{CNG}$-biomethane in transport will help to maintain an important asset - natural gas transport and storage infrastructure and intensify its use, especially storage capacities in Latvia, which also increase security of energy supply rates for the region;

4. contribution of sustainable natural gas technologies to the generation of electricity for use in electric mobility should be analyzed; 
5. fiscal support mechanisms and municipal-state support programs for the construction of CNG and CNG-methane filling stations both on natural distribution grid and off-grid should be established;

6. biomethane segment of CNG fuel sector has to be developed in the three Baltic countries simultaneously, with future biomethane injections into natural gas grid. Sporadic development of off-grid filling stations is also welcome in areas without natural gas distribution network coverage;

7. taking into account that the start-up period is mostly unprofitable because there are not enough vehicles to fuel yet, close cooperation between state authorities and municipalities is a key to launch and expand CNGbiomethane market throughout the Baltic countries over the next decade.

Based on these conclusions, future research can be initiated in order to establish to what extent and by what means the most economically sound and technically unchallenging synergy can be reached between the natural gas and RES in the Baltic countries (in energy production - for balancing of large-scale RES, primarily, wind energy installations; in transport - for establishment and sustainable development of CNG-biomethane market).

\section{ACKNOWLEDGEMENTS}

The research has been supported by the National Research Programme, project "Trends, Challenges and Solutions of Latvian Gas Infrastructure Development" (LAGAS) (No. VPP-EM-INFRA-2018/1-0003).

\section{REFERENCES}

1. Global Energy Statistical Yearbook. (2019). [Online]. [Accessed: 10 July 2019] https:// yearbook.enerdata.net/

2. European Environment Agency. (2018). Share of Renewable Energy in Gross Final Energy Consumption. [Online]. [Accessed: 7 July 2019] https://www.eea.europa.eu/ data-and-maps/indicators/renewable-gross-final-energy-consumption-4/assessment-3

3. Natural gas supply statistics. (2018). [Online]. [Accessed: 8 July 2019] https:// ec.europa.eu/eurostat/statistics-explained/index.php?title=Natural_gas_supply_ statistics\&oldid $=401136$

4. Savickis, J., Zeltins, N., Kalvītis, A., \& Ščerbickis, I. (2018). Natural Gas Development Prospects in the World, Europe, in the Baltic and Latvia. Energy and World Special Edition (dedicated to the 4th World Latvian Scientists' Congress), June 2018, Riga.

5. Verdolini, E., Vona, F., \& Popp, D. (2018). Bridging the Gap: Do Fast Reacting Fossil Technologies Facilitate Renewable Energy Diffusion? Energy Policy, 116, 242-256.

6. Directive 2014/94/EU of the European Parliament and of the Council of 22 October 2014 on the deployment of alternative fuels infrastructure Text with EEA relevance. [Online]. [Accessed: 31 July 2019] https://eur-lex.europa.eu/legal-content/en/ TXT/?uri=CELEX\%3A32014L0094

7. D'hont, L. (2018). EU Energy Union: Old Wine in New Bottles?. Master's Thesis, Ghent University. [Online]. [Accessed: 30 July 2019] https://lib.ugent.be/fulltxt/ 
RUG01/002/480/358/RUG01-002480358_2018_0001_AC.pdf

8. Wyns, T., Khatchadourian, A., \& Oberthür, S. (2014). EU Governance of Renewable Energy Post 2020 - Risks and Options. A Report for Heinrich Boll-Stiftung European Union. Institute for European Studies, Vrije Universiteit Brussel. [Online]. [Accessed: 22 July 2019] https://www.ies.be/files/eu_renewable_energy_governance_post_2020. pdf

9. 2030 Energy Strategy. [Online]. [Accessed: 31 July 2019] https://ec.europa.eu/energy/ en/topics/energy-strategy-and-energy-union/2030-energy-strategy

10. National Energy and Climate Plans (NECPs). (n.d.). [Online]. [Accessed: 31 July 2019] https://ec.europa.eu/energy/en/topics/energy-strategy-and-energy-union/governanceenergy-union/national-energy-climate-plans

11. Energy Union. (n.d.). [Online]. [Accessed: 30 July 2019] https://www.eceee.org/policyareas/energy-union/

12. European Federation for Transport and Environment. (2018). CNG and LNG for Vehicles and Ships - The Facts. [Online]. [Accessed: 30 July 2019] https://www. transportenvironment.org/sites/te/files/publications/2018_10_TE_CNG_and_LNG_for_ vehicles_and_ships_the_facts_EN.pdf

13. Sinn, H. (2016). Buffering Volatility: A Study on the Limits of Germany's Energy Revolution. CESIFO Working Paper No.5950.

14. Verfonder, K. (ed.) (2007). Nuclear Energy for Hydrogen Production. Schriften des Forschungszentrum Jülich Reihe Energietechnik, 58.

15. GE Energy. (2008). Analysis of Wind Generation Impact on ERCOT Ancillary Services Requirements. [Online]. [Accessed: 20 July 2019] https://www.nrc.gov/docs/ML0914/ ML091420464.pdf

16. Gaso. (2018). Summary on visit to Estonian CNG filling Stations (05.03.2018).

17. Mathiesen, P., \& Kleissl, J. (2011). Evaluation of Numerical Weather Prediction for Intra-Day Solar Forecasting in the Continental United States. Energy 85, 967-77.

18. Lithuanian Wind Power Association. (n.d.). [Online]. [Accessed: 30 July 2019] https:// lvea.lt/en/statistics/lithuanian-statistics/

19. Estonian Wind Power Association. (n.d.). [Online]. [Accessed: 30 July 2019] http:// www.tuuleenergia.ee/en/windpower-101/statistics-of-estonia/

20. Litgrid, AST, Elering. (2015). Review of RES Perspective in Baltic Countries till 2030. [Online]. [Accessed: 30 July 2019] https://elering.ee/sites/default/files/attachments/ Review_of_RES_perspective_in_Baltic_countries_till_2030.pdf

21. Nacionālais energétikas un klimata plāns (Nacionālā energétikas un klimata plāna aktualizètā versija (PROJEKTS)). (n.d.). [Online]. [Accessed: 30 July 2019] https:// em.gov.lv/lv/nozares_politika/nacionalais_energetikas_un_klimata_plans/

22. Latvenergo (Generation). (n.d.). [Online]. [Accessed: 15 July 2019] https://www. latvenergo.lv/eng/about_us/generation/

23. IPCC. Climate Change. (2014). Mitigation of climate change. Cambridge: Cambridge University Press.

24. Combustion Engine vs. Gas Turbine: Pulse Load Efficiency and Profitability. (n.d.). [Online]. [Accessed: 31 July 2019] https:/www.wartsila.com/energy/learn-more/ technical-comparisons/combustion-engine-vs-gas-turbine-pulse-load-efficiency-andprofitability

25. Kunickis, M., Balodis, M., Linkevičs, O., \& Ivanova, P. (2015). Flexibility Options of Riga CHP-2 Plant Operation under Conditions of Open Electricity Market. In 2015 IEEE 5th International Conference on Power Engineering, Energy and Electrical 
Drives (POWERENG), (pp. 548-553). 11-13 May 2015, Latvia, Riga, Riga Technical University.

26. CDF. (n.d.). CCGT: Improving the Environmental Performance of Fossil-fired Power Plants. Online]. [Accessed: 18 July 2019] https://www.edf.fr/en/edf/combined-cyclegas-turbine-power-plants

27. Ivanova, P., Sauhats, A., \& Linkevics, O. (2016). Towards Optimization of Combined Cycle Power Plants' Start-Ups and Shut-Down. In IEEE 16th International Conference on Environment and Electrical Engineering (EEEIC), 7-10 June 2016, Florence, Italy.

28. Hokerts, J. (2019). Saspiestās un sašķidrinātās dabasgāzes ienākšana Latvijas tirgū izaicinājumi un iespējas (presentation). In Conf. Energètikas nozares nākotne-iespējas un izaicinājumi. 7 March 2019, Riga.

29. Niedrite, I., Kreslins, A., Davis, A., \& Zeltins, N. (2013). Security of Gas Supply Risk Assessment Alternatives. In Proceedings of the 22 $2^{\text {th }}$ World Energy Congress, 820(14). 17 October 2013, Daegu, Korea.

30. Jansons, L., Zeltins, N., \& Savickis, J. (2016). The Latvian UGS Potential and Alternative Use of Underground Geological Structures. In e Proceeding of the 23rd World Energy Congress. 9-13 October 2016, Istanbul. ISBN: 978-605-89548-9-2

31. Rogulska, M., Bukrejewski, P., \& Krasuska, E. (2018). Biomethane as Transport Fuel. [Online]. [Accessed:30 July 2019] https://www.researchgate.net/publication/326376873 Biomethane_as_Transport_Fuel

32. Kampman, B., Leguijt, C., Scholten, T., Tallat-Kelpsaite, J., \& Brückmann, R. (2016). Optimal Use of Biogas From Waste Streams. An Assessment of the Potential of Biogas from Digestion in the EU Beyond 2020. CE Delf. [Online]. [Accessed: 30 July 2019] https://ec.europa.eu/energy/sites/ener/files/documents/ce_delft_3g84_biogas_ beyond_2020_final_report.pdf

33. Virši-A. (n.d.). Atklāj pirmo CNG jeb saspiestās dabasgāzes staciju Latvijāa [Online]. [Accessed: 10 July 2019] https://www.virsi.lv/lv/atklaj-pirmo-cng-staciju-latvija

34. Eesti Gaas. (2019). CNG and LNG in Europe and the Baltic (presentation). In Conf. Enerğêtikas nozares nākotne - izaicinājumi un iespējas. 7 March, 2019, Riga. [Online]. [Accessed: 5 June 2019] http://konferences.db.lv/conferences/energetika-2019/

35. Gaso. (2018). CNG transporta un uzpildes infrastruktūras attīstības perspektīvas (presentation).

36. Estonia: Largest CNG Filling Station Opens. (n.d.). [Online]. [Accessed: 31 July 2019] https://www.petrolplaza.com/news/22348

37. AST. (2018). Pārvades sistēmas operatora ikgadējais novērtējuma ziñojums. [Online]. [Accessed: 5 July 2019] http://www.ast.lv/sites/default/files/editor/20181001_PSO_ Zinojums_2017.pdf https://www.ies.be/files/eu_renewable_energy_governance_post_2020.pdf

38. Zemite, L., Kutjuns, A., Bode, I., Kunickis, M., \& Zeltins, N. (2018). Consistancy Analysis and Data Consultation of Gas System of Gas - Electricty Network of Latvia. Latvian Journal of Physics and Technical Sciences, 2018(1), 22-34 (DOI: 10.2478/lpts2018-0003) 


\title{
DABASGĀZES UN AER SINERGIJA BALTIJAS VALSTU \\ ENERGOAPGĀDES DROŠİBAS PAAUGSTINĀŠANAI \\ (PROBLĒMU NOSTĀDNE)
}

\author{
J. Savickis, N. Zeltiņš, L. Jansons
}

Kopsavilkums

Lai gan dabasgāze un atjaunojamie energoresursi ir divi nozīmīgi Baltijas valstu energoapgādes elementi gan šobrīd, gan pārskatāmā nākotnē, to konkurences aktualizācija prevalē pār abpusēji izdevīgas līdzāspastāvēšanas uzstādījumu. Globālā mērogā dabasgāze un AER arvien biežāk tiek uztverti kā galvenie pārejas uz oglekḷa mazietilpīgu ekonomiku elementi, taču Baltijas valstu kopīgās enerǵētikas nākotnes diskusija vairāk vērsta uz to pretnostatīšu, nevis konstruktīvas, abpusēji izdevīgas un tehniski pamatotas līdzāspastāvēšanas iespēju meklējumiem. Rakstā aktualizēti vairāki perspektīvi pētījumu un praktiskās darbības virzieni, kas vērsti uz dabasgāzes, pārbaudīta ātri reaǵējoša fosilā kurināmā, un AER sinerǵiju Baltijas valstu energoapgādes drošības paaugstināšanai un ilgtspējas stiprināšanai.

06.09.2019. 